AGRICULTURE AND BIOLOGY JOURNAL OF NORTH AMERICA

ISSN Print: 2151-7517, ISSN Online: 2151-7525, doi:10.5251/abjna.2012.3.12.506.509

(C) 2012, ScienceHuß, http://www.scihub.org/ABJNA

\title{
The impact of coloured lights on night-time colony management of the African honey bee (Apis mellifera adansonii)
}

\author{
${ }^{1}$ Edet, D. I, ${ }^{* 1}$ Oladele, A. T and ${ }^{2}$ Bekom R \\ ${ }^{1}$ Department of Forestry and Wildlife Management, University of Port Harcourt, Port Harcourt, \\ Nigeria \\ ${ }^{2}$ Department of Forestry and Wildlife Management, Cross River University of Technology, \\ Obubra Campus, Cross River State, Nigeria \\ "Corresponding author: kunleladele@yahoo.com, adekunle.oladele@uniport.edu.ng
}

\begin{abstract}
Torchlight plays an important part during colony inspection and honey harvesting in the tropics. The impact of coloured lights on night - time colony management of the African honey bees (Apis mellifera adansonii) was investigated in a Gmelina arborea plantation, Obubra, Nigeria. A Tanzanian top-bar bee hive coated with bee wax at the inner surface to attract bees and four identical torches modified to emit green, blue, red and white (control) lights were used. The four colours served as treatments for the study. The experiment was conducted for four weeks during the wet season in June/July, 2010. The mean numbers of honeybees attracted to each coloured light were: white (143.00), blue (122.50), green (97.75) and red (85.00). Analysis of variance showed that there were significant differences $(0.001, p \leq 0.05)$ among the various coloured lights in relation to number of bees attracted to each light while the Fisher's Least Significant Difference (LSD) revealed no significant difference between green and red coloured lights $(0.274$, $p \leq 0.05)$ alone. The red and green lights are therefore recommended for management of African honeybees at night.
\end{abstract}

Keywords: Torchlight, coloured light, African honeybees, night - time colony Management

\section{INTRODUCTION}

Beekeeping is one of the oldest branches of agriculture. It includes the collection and care of the bee swarms, pollination of field crops by bees, the study of bee products and the breeding of the bees for large scale honey production. Azuma, (2009) noted that honey bees produce valuable products including honey without competing with other activities of agriculture and forestry. Beekeeping practices is a global activity and capable of alleviating the livelihood of peasant populations by serving as important sources of nutrients, medicine and cash income in a developing economy such as Nigeria. According to Agoade (1977), beekeeping is surrounded by marginal understanding in tropical Africa and particularly Nigeria. Fadare et al., (2008) asserted that modern beekeeping was still at an infant stage in the Niger Delta region of Nigeria; however, Farinde et al (2005) recorded high level of knowledge of honey production by beekeepers in Oyo State, Nigeria.
In most parts of Nigeria, hive opening in beekeeping are sometimes done at night. High temperatures during the day make the bees active and sometimes difficult to handle (Aidoo, 2009). Worker bees become less active during the cooler times of the day and especially at night hours, (Yasuyuki, 2009). Most beekeepers therefore attend to their colonies late in the evening when temperatures are low and the bees are relatively calm, less defensive and easier to manipulate. At nights, torch lights are very important to beekeepers for visibility during hive inspection and honey harvesting, however, the aggressive African honey bees launch attack towards the direction of light and sting the keeper in the process.

A major disadvantage in the use of torches during inspection and harvesting is that bees and most insects are attracted to light at night, (Wallner et al, 1995, Henda et al., 1999a). Taylor, (1986) observed varied attraction to different light wavelengths in Lepidoptera and suggest standardization for each species of insects. Use of torchlight attracts bees in high numbers towards the light. Most beekeepers use smokers to drive the bees away during harvesting, 
while some engage torchlight, hence there is always conflict between the use of torchlight and use of the smoker, (Aidoo, 2009). Aggressive bees' sting in defense and protection of the colony, thereby causing death of the bees involved which could reduce bee population in the hive. A possible solution to this problem is based on the fact that insects are less attracted to certain coloured lights. The use of light with different colours during night - time colony management could be an alternative in honey harvesting with less sting in the night. Thus the objective of the study is to identify less attractive coloured lights to African honeybees during night time colony management. This study investigated the use of four (4) shades of colours (white, blue, red and green) in night time colony management of African honeybees.

\section{MATERIALS AND METHODS}

Study site: The experiment was conducted in the Gmelina arborea plantation of the Department of Forestry and Wildlife Management, Cross River University of Technology, Obubra Campus (Iongitude $8^{\circ} 12^{1} \mathrm{E}$ and Latitude $6^{\circ} 00^{1} \mathrm{~N}$ ) in June/July, 2010. Though the study was carried out in the plantation, the overall vegetation of the area is that of tropical rainforest of the Guinea-Congolian region with pockets of secondary forests and derived savanna.

Data Collection and analysis: Four identical torches were obtained from a local market. The first torch produced ordinary white light, while others were modified to emit blue, red, and green light respectively by cutting out a round piece of blue, red and green polythene sheets and fixing them on the glasses of each torch. Four sheets of black cloth measuring $50 \mathrm{~cm}^{2}$ each were obtained. Colonies of the Africa honeybee (Apis mellifera adansonii) were encouraged to colonize the beehives using beeswax as an attractant. Beeswax was thoroughly rubbed against the walls of the Tanzanian top-bar hive, the landing boards, the ridged portion and the wooden starter top-bars. Beeswax was decided because it is considered the best of all baits; it can quickly attract a swarm of bees. Beeswax is the most reliable bait because it retains its properties for a long time which is an advantage over other baits, (Akachukwu, 2005).

Enough evidence of hive colonization was observed after eight weeks, a strong colony of honeybees was chosen for the experiment (torchlight experiment). At $7.00 \mathrm{pm}$ when it is already dark, the colony was disturbed by tapping the side of the hive close to the entrance. A piece of black cloth measuring $50 \mathrm{~cm}^{2}$ was hung $20 \mathrm{~cm}$ from the entrance and the white light was shone on it. The number of bees attracted to the spotlight in the cloth in a five-minute period were counted and recorded. The experiment was repeated in the same colony with blue, red and green light from the modified torches in different days. The experiment was replicated four times within four weeks. Data were analyzed using completely Randomized Design (CRD) and Fishers Least Significant Difference (LSD) as describe by Akindele, (1996).

\section{RESULTS}

African honey bees were attracted to different coloured light shown on white cloth mounted close to the beehive entrance at night. Results from the experiment showed the mean attraction figures in four weeks as white light (143.0), Blue light (122.5), Green light (97.8) and red light (85.0) as shown in Fig.1.

Data was subjected to statistical analysis (ANOVA) to test the degree of variance in the African honey bee attraction to different colour lights, result revealed significant differences in the ability of different colour lights to attract honey bees, (Table 1).

Table 1: Analysis of Variance of honey bees attracted to different coloured lights

\begin{tabular}{|c|c|c|c|c|c|}
\hline \multicolumn{6}{|c|}{ Analysis of variance (ANOVA) of honey bees light } \\
attraction \\
\hline & $\begin{array}{c}\text { Sum of } \\
\text { Squares }\end{array}$ & df & $\begin{array}{c}\text { Mean } \\
\text { Square }\end{array}$ & F & Sig. \\
\hline Treatment & 8013.188 & 3 & 2671.063 & 10.793 & .001 \\
\hline Error & 2969.750 & 12 & 247.479 & & \\
\hline Total & $\mathbf{1 0 9 8 2 . 9 3 8}$ & $\mathbf{1 5}$ & & & \\
\hline
\end{tabular}

It was observed that the colour differences of the torch lights are highly significant $0.001,(p \leq 0.05)$. This implies that the colour effects in attracting honey bee when disturbed in the night are not equal. LSD result of multiple comparisons in (Table 2) showed significant differences within various coloured lights. The attraction of honey bees to white and blue light was not significant comparatively, $(0.090, p \leq 0.05)$. Also no significance difference was observed between green and red colour lights, $(0.274, p \leq$ 0.05). 
Table 2: Multiple comparisons of bees attracted to different coloured lights (LSD)

\begin{tabular}{|c|c|c|c|c|}
\hline $\begin{array}{c}\text { Types } \\
\text { of light }\end{array}$ & $\begin{array}{c}\text { Types of } \\
\text { light }\end{array}$ & $\begin{array}{c}\text { Mean } \\
\text { Difference }\end{array}$ & Std. Error & Sig. \\
\hline \multirow{4}{*}{ White } & Green & $45.25000^{\circ}$ & 11.12383 & .002 \\
\cline { 2 - 5 } & Blue & 20.50000 & 11.12383 & .090 \\
\cline { 2 - 5 } & Red & $58.00000^{*}$ & 11.12383 & .000 \\
\hline Green & White & $-45.25000^{*}$ & 11.12383 & .002 \\
\cline { 2 - 5 } & Blue & -24.75000 & 11.12383 & .046 \\
\cline { 2 - 5 } & Red & 12.75000 & 11.12383 & .274 \\
\hline Blue & White & -20.50000 & 11.12383 & .090 \\
\cline { 2 - 5 } & Green & 24.75000 & 11.12383 & .046 \\
\cline { 2 - 5 } & Red & 37.50000 & 11.12383 & .006 \\
\hline Red & White & $-58.00000^{*}$ & 11.12383 & .000 \\
\cline { 2 - 5 } & Green & -12.75000 & 11.12383 & .274 \\
\cline { 2 - 5 } & Blue & $-37.50000^{*}$ & 11.12383 & .006 \\
\hline
\end{tabular}

*. The mean difference is significant at $p \leq 0.05$ level.

\begin{tabular}{|c|c|c|c|c|c|}
\hline \multirow[t]{2}{*}{ 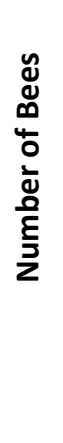 } & \multirow[t]{2}{*}{$\begin{array}{r}180 \\
160 \\
140 \\
120 \\
100 \\
80 \\
60 \\
40 \\
20 \\
0\end{array}$} & 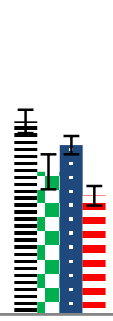 & 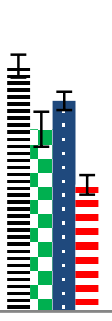 & 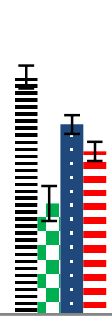 & 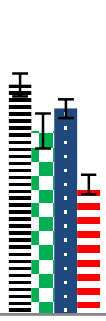 \\
\hline & & $\begin{array}{c}\text { Week } \\
1\end{array}$ & $\begin{array}{c}\text { Week } \\
2\end{array}$ & $\begin{array}{c}\text { Week } \\
3\end{array}$ & $\begin{array}{c}\text { Week } \\
4\end{array}$ \\
\hline & e Light & 122 & 155 & 150 & 145 \\
\hline & n Light & 90 & 115 & 70 & 116 \\
\hline & Light & 107 & 133 & 120 & 130 \\
\hline & ight & 75 & 80 & 103 & 82 \\
\hline
\end{tabular}

Fig. 1: African Honeybees attraction to different coloured lights in four (4) weeks

\section{DISCUSSIONS}

Beekeeping holds a great potential to contribute to poverty reduction and environmental protection including forest conservation through pollination activities of the bees. Studies have shown that honey bees are extremely visual animals, with a large portion of their brain dedicated to visual processing (Gronenberg, 2001). Ultraviolet light was observed to be the most effective spectral area for attracting insects at nights, (Blomberg et al., 1976). Most research using light traps has focused on monitoring of moths, and the literature reveals little about the attraction of beneficial insects such as honey bees to light, (Henda et al., 1999b). Collection of honey are traditionally done when it gets cool and after sunset to avoid attack of honey bees, (Yasuyuki, 2009). The efficiency of four light sources in attracting African honey bees with a view for improved night time hive management showed that red light attracted the least number of bees (85.0) out of the four different lights, (Fig.1). This is consistent with similar work in a neighbouring country Ghana where, (Aidoo, 2009) found that African honey bees are least attracted to red light than white light when disturbed in darkness. In this work bees were subjected to other coloured lights apart from red and white to ascertain the best coloured light for night time hive management. It was observed in the experiment that white (143.0) and blue (122.5) coloured lights attracted highest numbers of bees, this confirms the assertion of Henda et al., (1999c) that blue and cool white lights are about equally attractive to moths at night in Missouri, USA. Forager bee have been found much more positively phototactic in a laboratory assay, (Ben-Shahar et al., 2003), apparently forager bees population in the hive are usually larger than other casts.

Honey bees have well-developed color vision (Werner et al., 1988). Analysis of variance of bee attraction to light at night, (Table 1) showed significant differences in four tested coloured lights, (0.001, $p \leq 0.05)$, indicating that bees can be less aggressive at night under certain light conditions, calmness of African honey bees under specific lights reduces the fear and danger of sting. Fear of sting was identified as a major setback of bee keeping in Uganda, (Mujuni, 2012). African honey bees have been noted to be aggressive when disturbed, particularly those in high altitude areas as observed in western Uganda, (Corner, 1984, Aidoo, 2009). The Fisher's Least Significant Difference (LSD) procedure was used to test for differences among pairs of means and to recommend the coloured light which will be least attractive to the bees during night-time colony management of bees, (Table 2). Although, the red light attracted the least number of bees than the green light, LSD procedure showed that the mean numbers of bees attracted to the two colours are not significantly different $(0.274, p<0.05)$. White and blue coloured lights attraction were significantly different from green and red lights attraction. However, green and red coloured lights showed 
similarity in bee attraction, hence, ignite less aggression at night, and could be used in managing bee hives at night with fewer stings on the operator. Disturbed bees always sting the gloves of the person bearing the torchlight, thereby causing death of the bees involved and consequently reducing colony population.

\section{CONCLUSION}

Beekeeping is considered to be the most suitable off farm business for improving the livelihood of peasant farmers in sub-Sahara Africa, because, it requires minimum level of daily management and take off capital. The fear and danger of bee sting in apiculture can be reduced to barest minimum if appropriate coloured light is used during night inspection and management of bee hives in tropical Africa. Based on our findings, red or green light is recommended to enhance visibility and reduce sting in the management of African honey bee at night-time.

\section{REFERENCES}

Agoade, J.A. A. (1977). Beekeeping among the TIV, International field Journals of West_Africa, volume 42 .8-10

Aidoo, K. S. (2009). Bees and Red light, Bees for Development Journal, No 93

Akachukwu, C.O. (2005). Honey quality as affected by methods of harvesting and processing in Southern Nigeria. Journal of Agriculture, Agricultural Technology and Environment, Vol 1(1), 73 -82. Port Harcourt, Nigeria.

Akindele, S. O. (1996). Basic Experimental Designs in Agricultural Research. Montem Paperbacks, Akure, Nigeria. (ISBN 978-32973-8-4). 102pp

Azuma H. (2009). Introduction: Development of Beekeeping in Developing Countries and Practical Procedures - Case Study in Africa. Japan Association for International Collaboration of Agriculture and Forestry (JAICAF).

Ben-Shahar Y, Leung H.T, Pak W.L, Sokolowski M.B and Robinson, G. E. (2003). cGMP-dependent changes in phototaxis: a possible role for the foraging gene in honey bee division of labor. The Journal of Experimental Biology 206, 2507-2515

Blomberg, O., Itamies, J., and Kuusela, K. (1976). Insect catches in a blended and a black light-trap in northern Finland. Oikos 27, 57-63.

Corner, J. (1984). Apiculture and bee management problems in African countries. Pro. 3 International Conference on Apiculture in Tropical Climates. Pp 4144

Fadare, S.O., Ojo S.O. and Imoudu P.B. (2008). Analysis of Production Performance of Beekeeping in The Niger
Delta Area of Nigeria, Apiacta 43:37 - 48. International Federation of Beekeepers' Association Journal. Apimondia

Farinde, A.J, Soyebo, K.O. and Oyedokan, M.O. (2005). Exploration of Bee keeping as a coping strategy in a deregulated economy. Journal of Agricultural Extension Vol.8, Published by Agricultural Extension Society of Nigeria.

Gronenberg, W. (2001). Subdivisions of hymenopteran mushroom body calyces by their afferent supply. $J$. Comp. Neurol. 435, 474-489.

Henda N., Wayne C. B and Necibi, S. (1999a). Responses of Lepidoptera in Central Missouri to Traps with Different Light Sources, Journal of the Kansas Entomological Society Vol. 72 (1) 82-90. Published by: Kansas (Central States) Entomological Society Article Stable URL: http://www.jstor.org/stable/25085880

Henda N., Wayne C. B and Necibi, S. (1999b). Trapping of Phyllophaga sp. (Coleoptera: Scarabaeidae), Epicauta sp. (Coleoptera: Meloidae), and Green Stink Bugs (Hemiptera: Pentatomidae) with Different Sources of Light. Journal of the Kansas Entomological Society, Vol. 72(2), 222-225, Published by Kansas (Central States) Entomological Society, Retrieved Dec. 2012: http://www.jstor.org/stable/25085899

Henda Nabli, Wayne C. Bailey, and Necibi, S. (1999c). Beneficial Insect Attraction to Light Traps with Different Wavelengths. Biological Control 16, 185-188. Retrieved Dec. 2012: http://www.idealibrary.com

Mujuni A, Natukunda K and Kugonza D.R. (2012). Factors affecting the adoption of beekeeping and associated technologies in Bushenyi District, Western Uganda. Livestock Research for Rural Development. Volume 24, Article \#133. Retrieved December 5, 2012, from http://www.lrrd.org//rrd24/8/muju24133.htm

Taylor, R. A. (1986). Time series analysis of numbers of Lepidoptera caught in light traps in East Africa and the effect of moonlight on trap efficiency. Bull. Entomol. Res. 76: 593-606.

Wallner W.E, Humble L.M, Levin R.E, Baranchikov Y.N and Card, R.T. (1995). Response of Adult Lymantriid Moths to Illumination Devices in the Russian Far East, J. Econ. Entomol. 88(2): 337-342

Werner, A., Menzel, R. and Wehrhahn, C. (1988). Color constancy in the honeybee. J. Neurosci. 8, 156-159.

Yasuyuki M. (2009). Practices of Traditional Beekeeping Cases observed in district of Kitui Kamba in Eastern Province of Kenya: (In) Development of Beekeeping in Developing Countries and Practical Procedures Case Study in Africa. Japan Association for International Collaboration of Agriculture and Forestry (JAICAF). 